\title{
ANIMAL EXPLOITATION IN THE SUBSISTENCE BASE OF THE CHALCOLITHIC GÜLPINAR COMMUNITY
}

\section{KALKOLITIK GÜLPINAR TOPLUMU GEÇIM EKONOMISINDE HAYVANLARDAN FAYDALANMA}

\author{
Makale Bilgisi Article Info \\ Başvuru: 14 Eylül 2020 Received: September 14, 2020 \\ Hakem Değerlendirmesi: 21 Eylül 2020 Peer Review: September 21, 2020 \\ Kabul: 01 Aralık 2020 Accepted: December 01, 2020
}

DOI : $10.22520 /$ tubaar2020.27.003

\section{Evangelia PiŞKIN - Turan TAKAOĞLU**}

\begin{abstract}
This work examines the patterns of animal exploitation to reveal information on the subsistence base of the Chalcolithic settlers of Gülpınar in Northwestern Anatolia. The prehistoric site of Gülpınar, located beneath the remains of the Greek and Roman sanctuary of Apollo Smintheus (Smintheion) in northwestern Anatolia, has lately contributed much to our understanding of the Chalcolithic period particularly in western Anatolian littoral. Zooarchaeological evidence from phase II representing the early Chalcolithic 2 period and the succeeding phase III belonging to the Middle Chalcolithic period demonstrates that stock raising, hunting, fishing, and marine molluscs gathering formed an important part of the diet at both phases of occupation at Gülpınar. This zooarchaeological study overall provides a vivid picture of the Chalcolithic communities' animal exploitation patterns in northwestern Anatolia during a millennium-long period between $5300 \mathrm{BC}$ and $4300 \mathrm{BC}$.
\end{abstract}

Keywords: Gülpınar, Chalcolithic, zooarchaeology, subsistence base, animal husbandry, hunting, marine molluscs gathering.

Doç. Dr, Orta Doğu Teknik Üniversitesi, Yerleşim Arkeolojisi Programı, 06800 Ankara - Türkiye.

e-posta: ioannido@metu.edu.trＯRCID: 0000-0001-7727-3013

** Prof. Dr., Çanakkale Onsekiz Mart Üniversitesi, Fen/Edebiyat Fakültesi, Arkeoloji Bölümü, 17100 Çanakkale - Türkiye.

e-posta: takaoglu@comu.edu.tr ORCID: 0000-0001-9810-231 


\section{ÖZET}

Bu çalışma kuzey batı Anadolu'da Gülpınar kalkolitik yerleşimi toplumunun beslenme alışkanlıklarını ortaya koyabilmek için hayvanlardan nasıl yararlandığını ortaya koymaya çalışır. Apollon Smintheus Kutsal Alanı (Smintheion) kalıntıları altında ortaya çıarılan bulunan Gülpınar prehistorik yerleşimi son dönemlerde özellikle Batı Anadolu kıyı kesiminde Kalkolitik dönemi anlamamız konusunda önemli bilgiler ortaya koymuştur. Prehistorik Gülpınar yerleşiminde Erken Kalkolitik 2 dönemini temsil eden Tabaka II ve Orta Kalkolitik döneme ait Tabaka III buluntusu faunal veriler hayvan besiciliği, avcılık, balıkçılık ve deniz yumuşakça toplayıcılığının her iki evre boyunca besin ekonomisinin önemli bir bölümünü oluşturduğunu gösterir. Bu zooarkeolojik çalışma genel itibarıyla kuzey batı Anadolu'da yaklaşık olarak M.Ö. 5300 ile 4300 yılları arasında yaşayan Kalkolitik toplumlardan hayvanlardan besin amaçlı nasıl faydalanmış olabileceği konusunda canlı bir tablo sunar.

Anahtar Kelimeler: Gülpınar, Kalkolitik, zooarkeoloji, besin ekonomisi, hayvancılık, deniz yumuşakça toplayıcılığı. 


\section{INTRODUCTION}

Archaeological excavations conducted at the prehistoric settlement identified beneath the remains of the Greek and Roman Sanctuary of Apollo Smintheus (Smintheion) between 2004 and 2013 enhanced our understanding of the aspects of life and subsistence pursuits of the Chalcolithic inhabitants of north western Anatolia to a great extent. The animal remains examined here are derived from two successive Chalcolithic phases at Gülpınar. Phase II representing the Early Chalcolithic 2 period at Gülpınar is dated to $5320-4940 \mathrm{BC}$, while the succeeding phase III representing the Middle Chalcolithic period at the site is dated to $4930-4450 / 4300 \mathrm{BC}$ on the basis of radiocarbon determinations. The animal and marine mollusc remains were handpicked during the excavation and no sieving was carried out. They were mainly recovered from the architectural debris above the floors of architectural units A total of 5030 animal bones were examined from which 923 bones originate from phase II and the remaining 4107 samples belong to phase III. In addition to the animal bone assemblage, an additional 7961 marine shells were subjected to analysis in order show the ways how the Chalcolithic inhabitants of Gülpınar may have relied on marine molluses, such as oysters and mussels, to supplement their dietary needs in addition to what they gained from animals they raised, hunted, and fished.

\section{MATERIALS AND METHODS}

Animal bone fragments were identified at species or genus level. Those that could not be assigned to any of these two phases were put into respective "size" categories such as sheep-sized, cattle-sized, pig-sized, deer-sized and small mammals. The few bones that could not be separated even by size are categorized as unidentified. The materials were calculated by NISP (Number of Identified Specimens). This is done by counting the fragments with a few exceptions: horns and antlers are excluded from the calculations because not all species have them. Furthermore, antlers may be collected after being shed without the animal being hunted. Skull fragments are only counted if they retain part of the occipital condyle or a portion of the orbit or maxilla with teeth. Ribs and vertebrae are counted only in size categories (sheep-sized, pig-sized, cattle-sized) with the exception of the atlas and axis which are assigned and counted as their respective species. Ageing is based on the epiphyseal fusion of the long bones and the stages are recorded as "fused" when the bone has completed its growth or "unfused" when still immature. A further category of "fusing" denotes that an epiphysis is attached to the shaft but with the line of fusion still visible. This means that the bone is just at the age of completing its growth. The age of epiphyseal fusion follows the work of Silver. ${ }^{1}$ The assemblages are overall well-preserved but the bones from phase II appear to be less fragmented compared to phase III, taking into the account the higher number of unidentified specimens categorized only according to body size in phase III.

The remains of 7961 marine molluscs, on the other hand, are also examine here by using simple quantitative analysis to determine the gathering preferences of the inhabitants of Gülpınar. This number excludes sea-worn and fossilized shells that could have been collected from the seashore and brought to the site for purposes other than food. The quantification of the bivalves is based on counts of only left valve.

\section{DATA ON ANIMAL HUSBANDRY, HUNTING AND FISHING}

\section{Domestic Species}

Majority of the assemblages are made up of sheep/goats and sheep-sized bones (Table 1). Cattle (and cattlesized) bones also make up a high proportion. These species constitute the backbone of animal husbandry at the site. All other species are represented in much lower proportions. Sheep and goats amount to $46.05 \%$ in phase II and a lower $41.31 \%$ in phase III. The reduction may be due to many more bones being categorized as sheepsized in phase III compared to phasel II. More interesting is the large difference in ratio of cattle between the two Chalcolithic phases. In phase II we have a high $27.63 \%$ that falls to $15.85 \%$ in phase III. Here we again have an increase in the percentage of cattle-sized bone fragments; nevertheless, these differences are not enough to explain the change. If we add the sheep-sized category to the sheep/goats and cattle-sized category to cattle, then the score for sheep/goats at phase II $=52.88$ and phase III $=56.99$, whilst cattle will be phase II $=31.31$ and phase III $=27.1$. This makes sheep/goats more important at phase III than was initially shown, whilst cattle have still suffered a considerable reduction in proportion in phase III. Sheep and goats have been lumped together here in one category to simplify the comparisons; nevertheless, separation of the two species is important. This has been done and the share of sheep to goats is exactly the same for both phases and almost equal for both species. In exact numbers the sheep/goat ratio is $0.9 / 1.0$, making goats very slightly more frequent than sheep.

A recent faunal study at the Early Chalcolithic site of Uğurlu on the island of Gökçeada(Imbros) also contributes to our knowledge of the patterns of animal exploitation in the northeastern Aegean. Here, zooarchaeological and

Silver 1969. 
stable isotope ecology data point to a specialized animal activity based on the management of sheep and goat of local population (Atıc1 et al. 2019).

Especially interesting is the very low quantity of pig bones. Pig counts for only $3.03 \%$ of the assemblage in phase II and in phase III becomes even lower, scoring a mere $2.14 \%$. The lack of pig points to the possibility of a nomadic culture. Only one bone of a dog has been recognized in phase III.

\section{Wild Mammals}

A good number of wild species have been recognized at Gülpınar, most of them from phase III. These include wild goat, perhaps aurochs, wild pig, hare, fox, wild goat and three species of deer: red, fallow and roe deer. An equid is also present, which might have been a wild one. Wild pig is represented by three bones at phase III. However, most of the pig remains are from very young individuals that cannot be separated into wild or domestic. Therefore, we may have more wild pig but hunted at a young age. Auroch is not a confirmed identification. It is represented by a large humerus which was broken and could not be measured to ascertain its status as wild or domestic. It was also found in phase III. Four fragments of large wild goat horns were found in phase II and one in phase III (Fig. 1). Because horn and antlers were not included in the NISP values of Table 1, the contribution of wild goat remains unquantified and is only marked as present. The horn remains represent two individuals in phase II and one in phase III.

\begin{tabular}{|l|c|c|c|c||}
\hline & \multicolumn{2}{|c|}{ Phase II } & \multicolumn{2}{c|}{ Phase III } \\
\hline Species & No & \% & No & \% \\
\hline Sheep/goat, Ovis aries/Capra hircus & 425 & 46.05 & 1697 & 41.31 \\
\hline Sheep sized & 63 & 6.83 & 644 & 15.68 \\
\hline Cattle, Bos taurus & 255 & 27.63 & 651 & 15.85 \\
\hline Cattle sized & 34 & 3.68 & 462 & 11.25 \\
\hline Aurochs?, Bos primigenius & 0 & 0 & 1 & 0.02 \\
\hline Pig, Sus domestica & 28 & 3.03 & 88 & 2.14 \\
\hline Pig sized & 3 & 0.33 & 38 & 0.93 \\
\hline Wild pig, Sus scrofa & 0 & 0.00 & 3 & 0.07 \\
\hline Fallow deer, Dama dama & 18 & 1.95 & 61 & 1.48 \\
\hline Red deer, Cervus elaphus & 1 & 0.11 & 19 & 0.46 \\
\hline Roe deer, Capreolus capreolus & 4 & 0.43 & 5 & 0.12 \\
\hline Deer & 3 & 0.33 & 55 & 1.34 \\
\hline Deer sized & 9 & 0.98 & 50 & 1.22 \\
\hline Equid & 1 & 0.11 & 4 & 0.10 \\
\hline Onager/donkey, Equus hemionus/asinus & 0 & 0.00 & 2 & 0.05 \\
\hline Hare, Lepus europaeus & 2 & 0.22 & 25 & 0.61 \\
\hline Fox, Vulpus vulpus & 0 & 0.00 & 8 & 0.19 \\
\hline Dog, Canis familiaris & 0 & 0.00 & 1 & 0.02 \\
\hline Canid & 0 & 0.00 & 11 & 0.27 \\
\hline Small mammal & 0 & 0.00 & 7 & 0.17 \\
\hline Bird & 0 & 0.00 & 4 & 0.10 \\
\hline Heron, Ardea sp. & 0 & 0.00 & 3 & 0.07 \\
\hline Swan, Cygnus sp. & 0 & 0.00 & 1 & 0.02 \\
\hline Starling?, Sturnus sp. & 0 & 0.00 & 1 & 0.02 \\
\hline Duck, Anas sp. & 1 & 0.11 & 0 & 0.00 \\
\hline Seabream, Sparidae & 0 & 0.00 & 5 & 0.12 \\
\hline European bass / Dicentrarchus labrax & 0 & 0.00 & 1 & 0.02 \\
\hline White shark, Carcharias carcharodon & 0 & 0.00 & 1 & 0.02 \\
\hline Shark, Carcharinus sp. & 0 & 0.00 & 3 & 0.07 \\
\hline Shark, Sfyrna sp.? & 0 & 0.00 & 1 & 0.02 \\
\hline Tortoise, testudo sp. & 0 & 0.00 & 1 & 0.02 \\
\hline Rat, Ratus ratus & 0 & 0.00 & 4 & 0.10 \\
\hline Vole, Microtus sp. & 0 & 0.00 & 1 & 0.02 \\
\hline Unidentified & 76 & 8.23 & 250 & 6.09 \\
\hline Wild goat/Capra aegagrus & & & $*$ & \\
\hline Urchin, Echinus sp. & & $\mathbf{1 0 0 . 0 0}$ & 4107 & $\mathbf{1 0 0 . 0 0}$ \\
\hline Total & & & & \\
\hline & & & \\
\hline
\end{tabular}

Table 1: Gülpınar, species proportions by NISP. * = present / Tanımlanan türlerin sayısal oranlart 


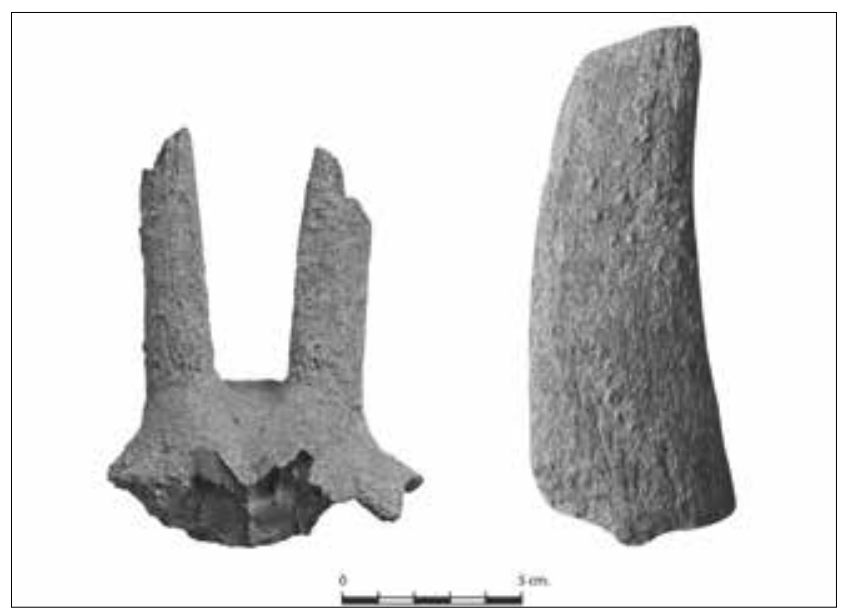

Figure 1: Gülpınar goat horns, domestic (left) and wild (right) / Gülpınar buluntusu keçi boynuzları, evcil (sol) ve yabani (să̆)

Most of the hunting appears to have been directed towards deer (Fig. 2). The most commonly hunt animal is the fallow deer for both periods, followed by red deer and then roe deer. Fallow deer hunting shows some reduction in phase III whilst red deer becomes more abundant in the same period. Roe deer is also rarer in phase III. Overall, the contribution of these species to the diet is small with fallow deer ranging from $1.95 \%$ in phase II to $1.45 \%$ in phase III, red deer constituting only $0.11 \%$ in phase II (one bone only) and $0.46 \%$ in phase III, and roe deer accounting for $0.43 \%$ in phase II and $0.12 \%$ in phase III. A slight reduction in deer hunting, especially fallow deer, considered together with some reduction in wild goat, may indicate environmental degradation.

Hare was also hunted in both phases of Gülpınar. Only two bones of this animal have been recorded in phase II, scoring $0.22 \%$, whilst in phase III the number increases

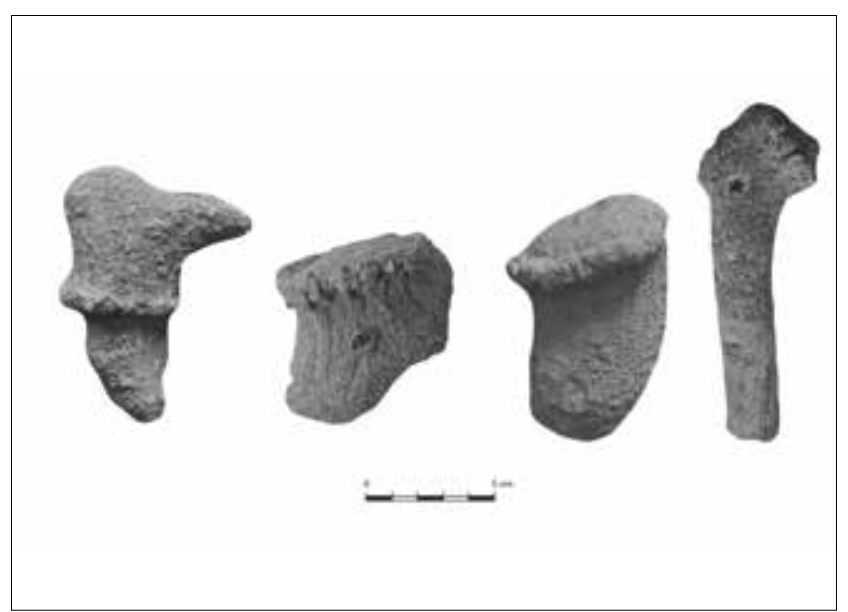

Figure 2: Red deer and fallow deer antlers. The left one preserves a tiny part of the skull, therefore it was not shed. The remaining three antlers were all shed / Klzıl geyik ve ala geyik boynuzlarl. Soldaki örnek kafatasından küçük bir parça içerir ve bu yüzden doğadan toplama değildir. Diğer üç boynuz doğadan toplamadır to 25 bones and $0.61 \%$. Fox is only attested in phase III with 8 bones $(0.19 \%)$. An additional 11 bone fragments belong to undetermined canids $(0.27 \%)$.

Equids are represented by one bone fragment in phase II whilst in phase III six equid bones were found. The bones are fragmentary and the only thing that can be said is that they belong to a small-sized equid. Amongst these fragments, one deserves special mention and holds clues to the actual species; this is a maxillary molar (M1 or M2). According to the criteria set out on the subject, ${ }^{2}$ the protocone shape is of the type Equus asinus and/or Equus hemionus (Asian wild ass). Given the geographical location of Gülpınar, the tooth more likely belongs to $\mathrm{E}$. hemionus. In addition, there is a navicular bone which is within the size range of such an equid (maximum length $35.5 \mathrm{~mm}$, maximum width $14.8 \mathrm{~mm}$ ).

\section{Fish}

A series of fish remains were recovered from phase III. A single vertebra recorded of a sea bass may be from the European bass (Dicentrarchus labrax ?), of rather small size. A further four molariform teeth plus a small fragment of mandible with one tooth from the family of Sparidae, sea bream, of rather large size, are also among them. Additional evidence for the exploitation of marine sources comes from three samples from the flotation of soil for the recovery of plant remains. There, many urchin spines were seen.

The most unusual finds are elements of sharks. There are four vertebrae (Fig. 4), three of which appear to belong to a Carharinus sp. (requiem shark), resembling more closely the Carcharinus obscurus or leucas, whilst the fourth looks

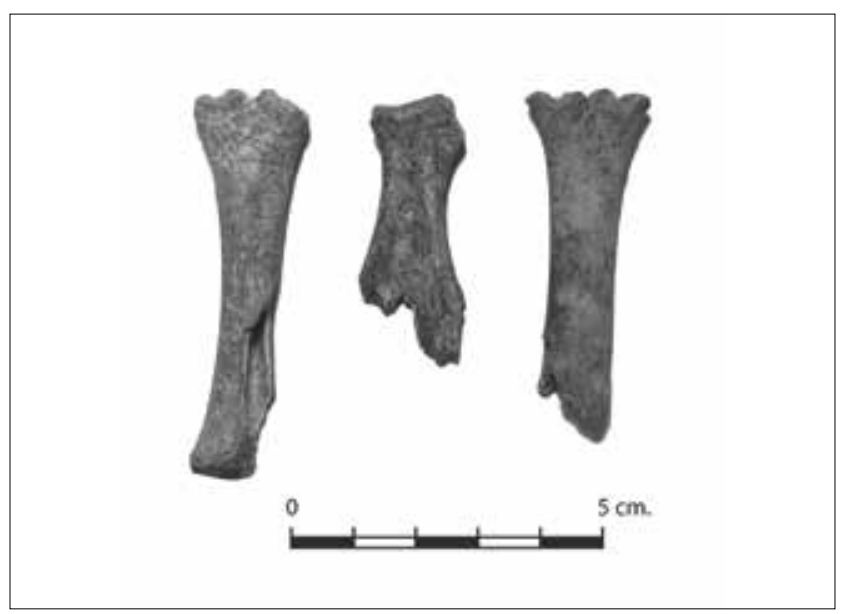

Figure 3: Neonatal sheep/goat from Gülpınar / Gülpınar buluntusu yeni doğan koyun/keçi kemikleri

2 Davis 1980. 


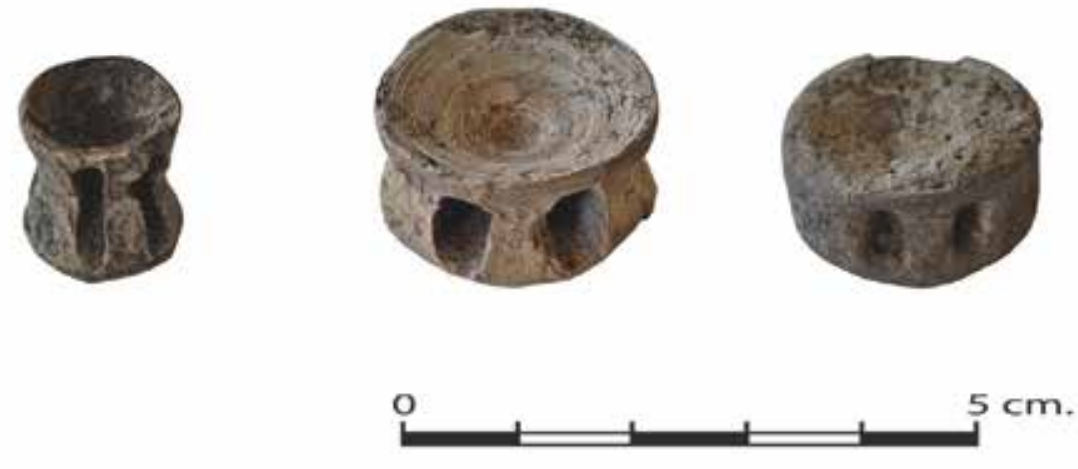

Figure 4: Centra of sharks. The first one might be a Sphyrna sp., the other three Carcharinus sp. / Köpekbalı̆̆ omurga kemikleri. En soldaki örnek Sphyrna sp. Olabilirken diğer üç örnek Carcharinus Sp. olmalıdır

closer to Sphyrna sp. (hammerhead shark). ${ }^{3}$ The size of these vertebrae is quite small. They may have come from rather small individuals, perhaps still young. Nevertheless, it must be noted that sharks have a huge number of vertebrae 4 which are very hard to define in order within the vertebral column in order to identify the species, and of course they vary in size. Caudal vertebrae are much smaller than the vertebrae of the mid-trunk. Both species of sharks inhibit warm shallow waters and it is possible they may have been captured relatively close to the seashore.

The most impressive though, is an upper tooth of Carcharodon carcharias (Fig. 5). It appears to be from the upper jaw. Because the position of the tooth on the jaw is impossible to specify, two measurements were taken to demonstrate its size. Its maximum length is 33.1 $\mathrm{mm}$ (from the lowest end of the root to the tip) and its maximum width is $44.5 \mathrm{~mm}$ (from just under the junction of the root to the enamel, which is the widest portion of the root). The identification and separation of this species from requiem and mako sharks is made on the grounds that the tooth displays no angularity; there is a ridge at the junction of enamel and root and the serrations are rather irregular. It is a wonder how the Chalcolithic settlers of Gülpınar may have captured a formidable white shark. Nevertheless, the presence of only one tooth cannot guarantee that it was truly fished. These remains cannot have come from scavenging dead sharks washed up on the shore because sharks sink to the bottom of the sea when they die. However, the remains such as vertebrae and teeth may be washed onto the seashore after decomposition of the body. Based on the limited number of finds, it is hard to confirm whether this is a case of skillfully fishing the most dangerous fish in the sea or beachcombing for the collection of special items.

\footnotetext{
Identification is based on the criteria published by Kozuch and Fitzgerald 1989.

4 Wheeler/Jones 1989.
}

\section{Birds}

A small assemblage of bird bones was found, mainly originating from phase III. Most of these bones were only shaft fragments and could not be identified at species level. The only thing we can say about them is that they belong to medium-sized birds. One duck (Anas sp.) was identified in phase II. From the succeeding phase III, we have three bones from a Heron (Ardea sp.), one fragmentary humerus, one phalange, and a tibiotarsus, also fragmentary), one fragmentary carpometacarpus from a Swan (Cygnus sp.), and the humerus (distal portion only) of a songbird. Songbirds (Passeriformes) are notoriously difficult to assign to a species. This is a small-sized one and is categorized as belonging to the family of Sturnus sp., according to the criteria of Wójcik. ${ }^{5}$ It is most likely a starling (Sturnus vulagris), a very common bird often seen in the Turkish countryside. This assemblage is rather limited; however, it attests to exploitation of the wetlands and occasional bird hunting.

\section{Rodents and Reptile}

Only one bone fragment from a tortoise shell has been recovered from phase III. Four bones of rat (Ratus ratus) were found of which three are the femora and one the humerus. In addition, a fragmentary mandible, and the teeth M1 and M3 of Microtus sp., (vole) have been found. Rats and voles are very common and often found in archaeological deposits, but since these are burrowing animals, it is often hard to decide whether their bones come from the Chalcolithic period or are later intrusions.

\footnotetext{
$5 \quad$ Wójcik 2002.
} 


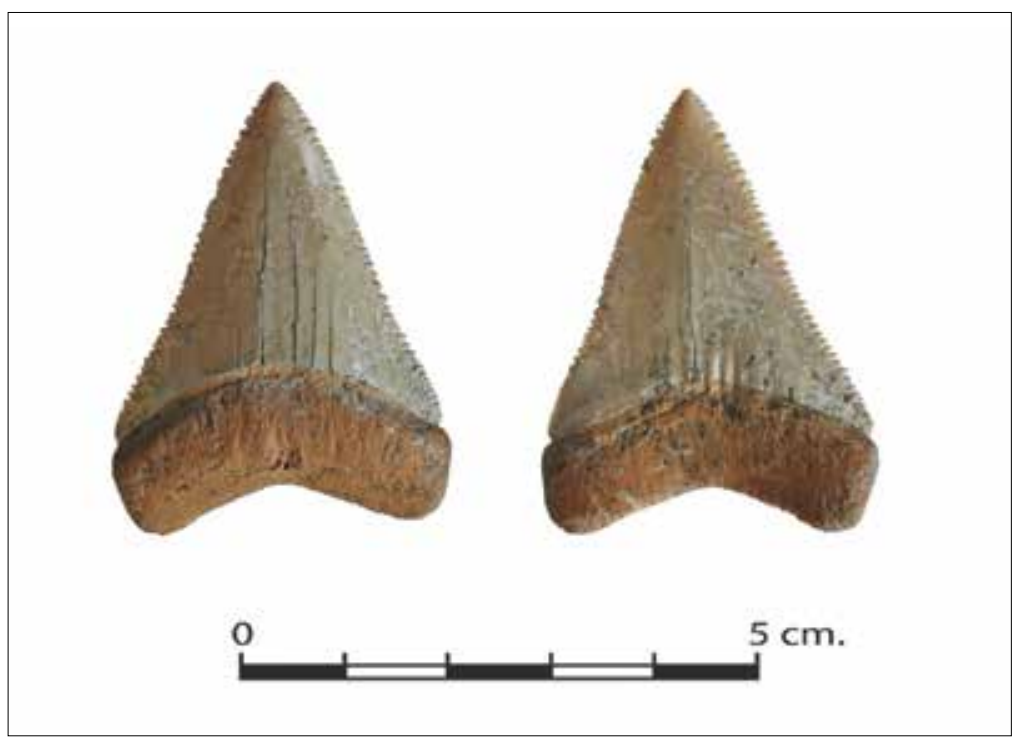

Figure 5: Tooth of white shark / Beyaz köpekbalı̆̆ dişi

\begin{tabular}{|c|c|c|c|c|}
\hline Context & Cattle & Goat & Deer & Sheep \\
\hline Phase II & 8 & $35(6)$ & $5(3 \mathrm{~S})$ & 3 \\
\hline Phase III & 23 & $46(1)$ & $24(11 \mathrm{~S})$ & 2 \\
\hline
\end{tabular}

Table 2: Horn and antlers by context / Evrelere göre hayvan boynuzlar

\begin{tabular}{|l|l|l|l|l|l|l|l|l|l||}
\hline Cattle & Months & Phase II & & & Total & Phase III & & & Total \\
\hline Fusion stage & & F & UF & FG & & F & UF & FG & \\
\hline Scapula, distal & 7 to 8 & 2 & 1 & & & 10 & & & \\
\hline Pelvis & 7 to 10 & 2 & & 1 & & 12 & & & \\
\hline TOTAL No & $\mathbf{7}$ to $\mathbf{1 0}$ & $\mathbf{4}$ & $\mathbf{1}$ & $\mathbf{1}$ & $\mathbf{6}$ & $\mathbf{2 2}$ & $\mathbf{0}$ & $\mathbf{0}$ & $\mathbf{2 2}$ \\
\hline Total \% & & $\mathbf{6 6 . 7}$ & $\mathbf{1 6 . 7}$ & $\mathbf{1 6 . 7}$ & $\mathbf{1 0 0 . 0}$ & $\mathbf{1 0 0 . 0}$ & $\mathbf{0 . 0}$ & $\mathbf{0 . 0}$ & $\mathbf{1 0 0 . 0}$ \\
\hline 1st phalange & $13-15$ & 17 & 1 & & & 32 & 4 & & \\
\hline Humerus, distal & $15-18$ & 2 & & & & 4 & 1 & 1 & \\
\hline Radius, proximal & $15-18$ & 1 & & & & 6 & & & \\
\hline 2nd phalange & 18 & 15 & & & & 21 & 1 & & \\
\hline TOTAL No & $\mathbf{1 3}$ to $\mathbf{1 8}$ & $\mathbf{3 5}$ & $\mathbf{1}$ & $\mathbf{0}$ & $\mathbf{3 6}$ & $\mathbf{6 3}$ & $\mathbf{6}$ & $\mathbf{1}$ & $\mathbf{7 0}$ \\
\hline Total \% & & $\mathbf{9 7 . 2}$ & $\mathbf{2 . 8}$ & $\mathbf{0 . 0}$ & $\mathbf{1 0 0 . 0}$ & $\mathbf{9 0 . 0}$ & $\mathbf{8 . 6}$ & $\mathbf{1 . 4}$ & $\mathbf{1 0 0 . 0}$ \\
\hline Tibia, distal & $24-30$ & 5 & & 1 & & 4 & 5 & & \\
\hline Metacarpal, distal & $24-36$ & 7 & 1 & & & 6 & 1 & & \\
\hline Metatarsal, distal & $27-36$ & 3 & 1 & & & 7 & 1 & & \\
\hline TOTAL No & $\mathbf{2 4}$ to $\mathbf{3 6}$ & $\mathbf{1 5}$ & $\mathbf{2}$ & $\mathbf{1}$ & $\mathbf{1 8}$ & $\mathbf{1 7}$ & $\mathbf{7}$ & $\mathbf{0}$ & $\mathbf{2 4}$ \\
\hline Total \% & & $\mathbf{8 3 . 3}$ & $\mathbf{1 1 . 1}$ & $\mathbf{5 . 6}$ & $\mathbf{1 0 0 . 0}$ & $\mathbf{7 0 . 8}$ & $\mathbf{2 9 . 2}$ & $\mathbf{0 . 0}$ & $\mathbf{1 0 0 . 0}$ \\
\hline Calcaneum & $36-42$ & 1 & 1 & & & 5 & 3 & & \\
\hline Femur, proximal & 42 & & 1 & & & 2 & 2 & & \\
\hline Humerus, proximal & $42-48$ & & 1 & & & 1 & 1 & & \\
\hline Radius, distal & $42-48$ & & & & & 5 & 1 & 1 & \\
\hline Ulna, proximal & $42-48$ & 1 & & & & 2 & 1 & 1 & \\
\hline Femur, distal & $42-48$ & & 1 & & & 3 & 1 & & \\
\hline Tibia, proximal & $42-48$ & & & & & & 2 & & \\
\hline TOTAL No & $\mathbf{3 6}$ to $\mathbf{4 8}$ & $\mathbf{2}$ & $\mathbf{4}$ & $\mathbf{0}$ & $\mathbf{6}$ & $\mathbf{1 8}$ & $\mathbf{1 1}$ & $\mathbf{2}$ & $\mathbf{3 1}$ \\
\hline Total \% & & $\mathbf{3 3 . 3}$ & $\mathbf{6 6 . 7}$ & $\mathbf{0 . 0}$ & $\mathbf{1 0 0 . 0}$ & $\mathbf{5 8 . 1}$ & $\mathbf{3 5 . 5}$ & $\mathbf{6 . 5}$ & $\mathbf{1 0 0 . 0}$ \\
\hline Total bones & & 56 & 8 & 2 & 66 & 120 & 24 & 3 & 147 \\
\hline
\end{tabular}

Table 3: Cattle ageing. Abbreviations $\mathrm{F}=$ fused, $\mathrm{UF}=$ unfused, $\mathrm{FG}=$ Fusing / Sığırların yaş durumu 


\section{Horns and Antlers}

At Gülpınar, an abundance of horns and antlers were found. Their frequencies are shown at Table 2. Some of them were relatively large pieces but most were broken and none of them were complete enough to take useful measurements. An attempt was made to match the fragments to each other so as possibly not to count many times the same fragmented horn. Only in a few cases was this possible. Therefore, several of these fragments may have come from the same horn/antler. Two observations are interesting here. Firstly, majority of horns belong to goats, although several pieces were large enough to attribute to wild goats (Fig. 1). Those considered to be wild goats are noted in Table 2 in parenthesis next to the total number of horns. Secondly, many of the antlers were shed; that is, they were collected from the forest after they had been shed by the deer. Only in one case was the antler found still attached to the skull (Fig. 2). The rest of the antlers were in smaller pieces and without the pedicle portion of it which could inform us of the circumstances of the antler (shed or not). The number of shed antlers is noted in parenthesis in Table 2, next to the total number of antlers found in each context. Amongst the shed antlers, one belongs to a roe deer, four to red deer and five to fallow deer. The rest could not be identified with certainty. Deer normally shed their antlers between January and April

\section{Neonatal Animals}

Several neonatal animal bones were found, all of them originating from phase III (Pl. 14.3). Of these, 12 belong to sheep/goat, 10 are of sheep-size, 3 belong to cattle, 1 to pig and 1 to deer (most likely red deer). These bones are very interesting because they show the breeding of domestic animals at the site and that the occupants of Gülpınar were present there during the birth of these animals; therefore, this could be used as evidence of seasonality or duration of occupation. Sheep are usually born between February and April. Goats are usually in season between September and March and the kidding period will occur sometime from January to about August. Pigs may have two litters a year, while the calving season for cattle may be in the autumn or spring. No doubt, the birthing season of domestic animals can be manipulated by humans to fit their husbandry needs. Wild fauna obviously cannot, and red deer births occur from mid-May to mid-July.

\section{Ageing}

Ageing profiles have been reconstructed for the sheep/ goats and cattle. Pig bones were too few to make any meaningful statistical analysis. The cattle ageing profile for phase II has been constructed on a total of 66 long bones and for phase III on 147 bones. Overall, there is a preference for culling the cattle after their second year, with most deaths occurring at the age of 3-4 and after. There are some differences in the pattern between the two phases. In phase II we have $16.7 \%$ of the flock slaughtered under the age of 6-10 months and another $16.7 \%$ exactly at that age. Nevertheless, the number of bones on which these percentages are based is very small, one in each category, and they may represent one or a maximum of two individuals. In contrast, in phase III we found no animal slaughtered at this age but all 22 bones belonging to this age stage were all fused. Most of the cattle for both phases survive the stage of $13-18$ months. In more detail, only $2.8 \%$ and $1.4 \%$ are slaughtered at this age interval for phase II and phase III, respectively. Again, this information comes from only one bone in each phase. For the age of 24 to 36 months, a peak in slaughter is observed, with $11.1 \%$ of the flock being slaughtered under this age for phase II and a considerable $29.2 \%$ for phase III. Most of the animals survive this age at phase II (83.3\%) but fewer do in phase III $(70.8 \%)$. Most of the slaughter takes place at the age of 36 to 48 months. In phase II only $33.3 \%$ of the cattle remain alive after this age whilst $66.7 \%$ are killed. In phase III, the rate of slaughter is much higher than the previous stages $(35.5 \%$ plus $6.5 \%$ for at least one animal slaughtered exactly at this age) but the surviving flock is considerably bigger $(58.1 \%)$ compared to phase II.

In conclusion, it can be said that in phase II the cattle are slaughtered at a younger age and at frequent intervals spread through all ages with most of the deaths occurring between 3 and 4 years old. In contrast, in phase III many more cattle survive their fourth year and we have no deaths under 10 months. However, there is frequent slaughter at the age of about 1.5 years and even more between the 2nd and 3rd year; testifying to the use of cattle for meat. Overall, the economy of the two phases apparently aims at a mixed strategy of obtaining both meat and secondary products; nonetheless, phase III exploitation appears to be more strongly directed towards secondary products, based on the large number of animals kept to an old age.

The sheep and goat mortality profile could be reconstructed on 180 bones for phase II and 558 for phase III. There were few deaths recorded for the first year of the animals in both phases. A massive $93.0 \%$ for phase II and $91.2 \%$ for phase III survived the age of 6 to 10 months, with only a few lambs and kids slaughtered that young. The first peak in slaughter in phase II occurs during the second year with animals between the age of 13 to 24 months, when about $23.4 \%$ (21.7\% unfused and $1.7 \%$ fusing) are killed during this time span. The same age interval has fewer deaths for phase III, when only 


\begin{tabular}{|c|c|c|c|c|c|c|c|c|c|}
\hline Sheep/Goat & Months & $\begin{array}{c}\text { Phase } \\
\text { II }\end{array}$ & & & & $\begin{array}{l}\text { Pha } \\
\text { se } \\
\text { III } \\
\end{array}$ & & & \\
\hline Fusion stage & & $F$ & UF & FG & Total ac & $F$ & UF & FG & Total ac \\
\hline Scapula, distal & 6 to 10 & 16 & & 1 & & 49 & 3 & 2 & \\
\hline Pelvis & 6 to 10 & 9 & & & & 45 & 2 & & \\
\hline Humerus, distal & 10 & 26 & 3 & & & 53 & 4 & 4 & \\
\hline Radius, proximal & 10 & 15 & 1 & & & 40 & & 3 & \\
\hline TOTAL No & 6 to 10 & 66 & 4 & 1 & 71 & 187 & 9 & 9 & 205 \\
\hline Total \% & & 93.0 & 5.6 & 1.4 & 100.0 & 91.2 & 4.4 & 4.4 & 100.0 \\
\hline 1st phalange & $13-16$ & 20 & 4 & & & 61 & 17 & 2 & \\
\hline 2nd phalange & $13-16$ & 2 & 1 & & & 20 & & 1 & \\
\hline Metacarpal, distal & $18-24$ & 4 & 3 & & & 22 & 7 & & \\
\hline Tibia, distal & $18-24$ & 20 & 5 & 1 & & 73 & 4 & 5 & \\
\hline TOTAL & 13 to 24 & 46 & 13 & 1 & 60 & 176 & 28 & 8 & 212 \\
\hline Total \% & & 76.7 & $\begin{array}{l}21 . \\
7\end{array}$ & 1.7 & 100.0 & 83.0 & 13.2 & 3.8 & 100.0 \\
\hline Metatarsal, distal & $20-28$ & 3 & 3 & 1 & & 22 & 7 & & \\
\hline Ulna, proximal & 30 & 5 & 2 & & & 3 & 5 & & \\
\hline Calcaneum & $30-36$ & 9 & 3 & & & 16 & 10 & 1 & \\
\hline Femur, proximal & $30-36$ & 2 & 1 & & & 3 & 6 & & \\
\hline TOTAL & 20 to 36 & 19 & 9 & 1 & 29 & 44 & 28 & 1 & 73 \\
\hline Total \% & & 65.5 & $\begin{array}{l}31 . \\
0\end{array}$ & 3.4 & 100.0 & 60.3 & 38.4 & 1.4 & 100.0 \\
\hline Radius, distal & 36 & 6 & 7 & & & 17 & 20 & 1 & \\
\hline Humerus, proximal & $36-42$ & 1 & & & & & 3 & & \\
\hline Femur, distal & $36-42$ & 2 & 3 & & & 10 & 8 & & \\
\hline Tibia, proximal & $36-42$ & 1 & & & & 4 & 4 & 1 & \\
\hline TOTAL & 36 to 42 & 10 & 10 & 0 & 20 & 31 & 35 & 2 & 68 \\
\hline Total \% & & 50.0 & $\begin{array}{l}50 . \\
0 \\
\end{array}$ & 0.0 & 100.0 & 45.6 & 51.5 & 2.9 & 100.0 \\
\hline Total bones & & 141 & 36 & 3 & 180 & 438 & 100 & 20 & 558 \\
\hline
\end{tabular}

Table 4: Sheep/Goat ageing. Abbreviations F = fused, UF $=$ unfused, $\mathrm{FG}=$ Fusing / Koyun ve keçilerin yaş durumu

$17 \%(13.2 \%$ and $3.8 \%)$ of the flock was slaughtered. Considerably higher is the death rate in the third year of the animals, when only $65.5 \%$ of the flock survive at phase II and $60.3 \%$ at phase III. At the age of 36 to 42 months, about half of the flock will have already been slaughtered at phase II. A similar but slightly higher number than this will be killed in phase III, where less than half $(45.6 \%)$ escape slaughter. The two phases appear rather similar in the husbandry of sheep and goat with minor variations, which are mostly characterized by an elevated slaughter in the second year of the animals at phase II, perhaps indicating a more meat-orientated economy than in phase III. The deaths saved in the second year of phase III are spread throughout the 3rd and 4th years of the flock when more culling occurs in comparison to phase II. Here, more animals are kept alive and slaughtered at lower rates, with a peak of culling for both sites at the age of about four.

Management of the sheep and goat flocks is clearly directed towards a variety of products. Meat and secondary products as well as the security of the herd are all important. Both phases staggered the slaughter to take advantage of various products. Animals in their second and third year are most profitable for meat whilst older animals, especially those kept for four years, are used for their secondary products. It appears that phase II settlers were either more interested in meat production by intensifying the slaughter in the second year of their animals; or alternatively, they had less resources to hand that would allow them to keep a large number of animals throughout the winter and into their third year. In phase III, the settlers of the site are clearly able to preserve their flocks for longer. This strategy is beneficial for the security and growth of the flock to larger numbers as it allows one more year of maturity for the animals. This would have enabled ancient shepherds to keep the best ewes and rams alive longer for reproduction and secondary products and to single out the weaker ones for slaughter.

\section{DIETARY USE OF MARINE MOLLUSCS}

The recovery of several loci with hearths surrounded by deposits of marine molluses that appear to be left over from meals is of great archeological importance to better understand the subsistence pursuits of the settlers of the site (Yavşan 2010). Due to their dietetic value, the inhabitants of Gülpınar may have relied on marine molluscs, such as oysters and mussels, to supplement their protein needs in addition to what they gained from animals they raised and hunted. At Gülpınar, marine molluscs could have easily been gathered from the shallow bays and rocky bottoms on the Aegean shoreline, about $1 \mathrm{~km}$ west of the site. Although marine mollusc gathering requires little or no specific gear, it is difficult to know if it was exercised by specialized individuals or groups at Gülpınar. It is plausible that the procurement of marine molluscs may have been a traditional activity passed from one generation to the next.

The quantity of marine shells recovered from Gülpınar points to the systematic exploitation of molluses for daily dietary purposes. The shell deposits were found in several locations within the site at Gülpınar. They are often found around the hearths in the food preparation areas inside buildings or in courtyards within the settlement. They clearly represent refuse thrown away by the residents. There are also cases where shells left over after eating were deposited outside the surrounding wall of the settlement. Deposits of marine shells were also uncovered inside a storage pit dug into the earth outside the settlement. A high concentration of marine shells consisting of edible species throughout the settlement clearly testifies to the settlers' dependence on marine resources to supplement their daily diet. 


\begin{tabular}{|l|c|c|c|}
\hline & & Quantity & \\
\hline Bivalves & Phase II & Phase III & Total \\
\hline Mytilus galloprovincialis & 301 & 875 & 1176 \\
\hline Solen marginatus & 157 & 946 & 1103 \\
\hline Cerastoderma glaucum & 413 & 545 & 958 \\
\hline Ostrea edulis & 261 & 490 & 751 \\
\hline Ruditapes decussatus & 123 & 186 & 309 \\
\hline Glycymeris glycymeris & 94 & 118 & 212 \\
\hline Acanthocardia tuberculata & 87 & 122 & 209 \\
\hline Arca noae & 9 & 29 & 38 \\
\hline Spondylus gaederopus & 13 & 24 & 37 \\
\hline Flexopecten glabra & 5 & 11 & 16 \\
\hline Pecten jacobaeus & 3 & 9 & 12 \\
\hline Donax trunculus & - & 6 & 6 \\
\hline Mimachlamys varia & - & 3 & 3 \\
\hline Pholas dactylus & - & 2 & 2 \\
\hline Venus verrucosa & - & 1 & 1 \\
\hline & $\mathbf{1 4 6 6}$ & $\mathbf{3 3 6 7}$ & $\mathbf{4 8 3 3}$ \\
\hline
\end{tabular}

Table 5: Quantity and sum of bivalves in phases II and III at Gülpınar. (Quantification is based on counts of left valve. Fossilized and sea-worn marine shells are excluded from the quantification) / Gülpınar'da evrelere göre çift kabukluların sayısal oranı (Hesaplamada sadece sol kabuklar dikkate alınmış, fosilleşmiş ve denizin aşındırdığ örnekler bu orana dahil edilmemiştir)

\begin{tabular}{|l|c|c|c|}
\hline & & Quantity & \\
\hline Gastropods & Phase II & Phase III & Total \\
\hline Patella coerulae & 438 & 875 & 1313 \\
\hline Patella rustica & 235 & 689 & 924 \\
\hline Hexaplex trunculus & 149 & 224 & 373 \\
\hline Murex brandaris & 138 & 176 & 314 \\
\hline Thais haemastoma & 7 & 38 & 45 \\
\hline Conus ventricosus & 11 & 28 & 39 \\
\hline Phorcus turbinatus & 29 & 9 & 38 \\
\hline Euthria cornea & 10 & 24 & 34 \\
\hline Cerithium vulgatum & 9 & 15 & 24 \\
\hline Columbella rustica & 3 & 11 & 14 \\
\hline Nassarius nitidus & 4 & - & 4 \\
\hline Cyclope neritea & - & 3 & 3 \\
\hline Cymatium corrugatum & - & 3 & 3 \\
\hline & $\mathbf{1 0 3 3}$ & $\mathbf{2 0 9 5}$ & $\mathbf{3 1 2 8}$ \\
\hline
\end{tabular}

Table 6: Quantity and sum of gastropods in phases II and III at Gülpınar. (Fossilized and sea-worn marine shells are excluded from quantification) / Gülpınar'da evrelere göre gastropod oranları (Fosilleşmiş ve denizin aşındırdığı örnekler bu orana dahil edilmemiştir

Total of 7961 marine shells were recorded in the cultural deposits of the settlement from 2004 to 2013. 15 species of bivalves and 13 species of gastropods were identified at both phase II and phase III at Gülpınar. The bivalve species represented at Gülpınar are: Cerastoderma glaucum, Ostrea edulis, Mytilus galloprovincialis, Solen marginatus, Ruditapes decussatus, Glycymeris glycymeris, Acanthocardia tuberculata, Arca noae, Spondylus gaederopus, Flexopecten glabra, Pecten jacobaeus, Donax trunculus, Mimachlamys varia, Pholas dactylus, and Venus verrucosa. Edible molluscs representing bivalvia such as Solen marginatus, Mytilus galloprovincialis and Ruditapes decussatus appear to be the most common species identified in the food preparation or disposal areas at the site. Ostrea edulis is also frequently encountered among the architectural debris of buildings representing both phases at the site.

The gastropod species represented at Gülpınar, on the other hand, are Patella coerulae, Patella rustica, Hexaples trunculus, Murex brandaris, Thais haemastoma, Conus ventricosus, Phorcus turbinatus, Euthria cornea, 
Cerithium vulgatum, Columbella rustica, Nassarius nitidus, Cyclope neritea, and Cymatium corrugatum. The bivalvia assemblage is dominated mainly by edible species, implying that they were exploited mainly for sustenance. Among the gastropods, the limpets (Patella coerulea and Patella rustica) were commonly used for dietary purposes at Gülpınar. The limpets, clinging to rocks at the water's edge, are still commonly found in the aquatic habitat of the shallow bays near the site.

Marine mollusc gathering was a subsistence strategy that existed at both phase I and succeeding phase III at Gülpınar. Several locations within the settlements present evidence for a high concentration of marine shells left over from food preparation activities. For example, a deposit of marine shells composed of Solen marginatus, Ruditapes decussatus, and Mytilus galloprovincialis was identified on the floor of Building $\mathrm{K}$ in phase II (Fig. 6). These marine shells found scattered around the hearth and oven in Building $\mathrm{K}$ all belong to edible species.

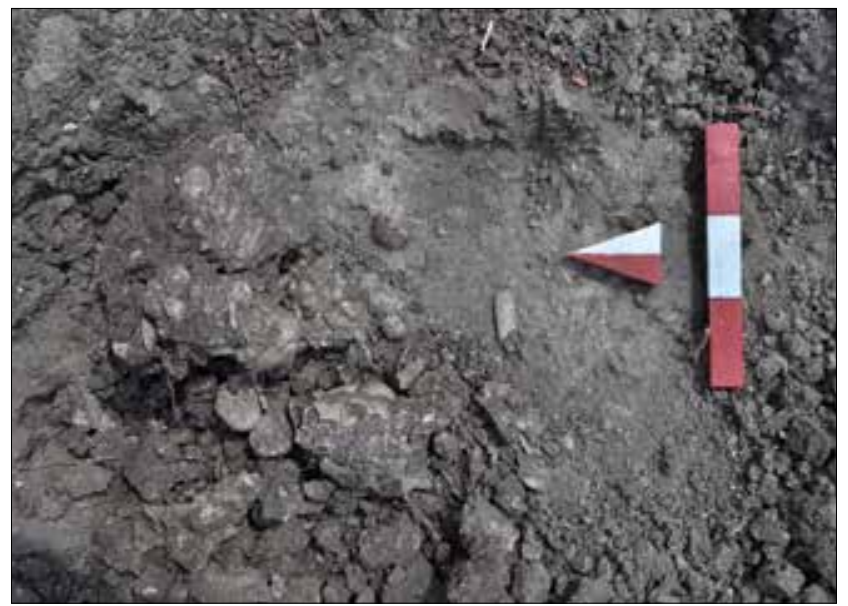

Figure 6: A view of marine shell deposit composed of Solen marginatus, Ruditapes decussatus and Mytilus galloprovincialis identified around a hearth and oven in Room 33 in Building $\mathrm{K}$ in Sector 2, phase II / Tabaka 2, Sektör 2, K Yapısı'nda bulunan Solen marginatus, Ruditapes decussatus ve Mytilus galloprovincialis kabukları içeren yığına ait bir görüntü

Middle Chalcolithic settlers of Gülpınar apparently continued to rely on similar edible species of marine molluscs to supplement their diet. A heap of Hexaples trunculus shells was uncovered with a grooved stone weight on the corner of Building $\mathrm{J}$ in Sector 1 (Fig. 7). This is a rare example where marine shells were recovered with fishing-related gears. This deliberate deposition of molluscs with a stone weight may indicate that they were brought to the site with along with the fishing tackle used after returning to the settlement from gathering.

It seems that marine shells left over from meals were removed from living units. Two different deposits

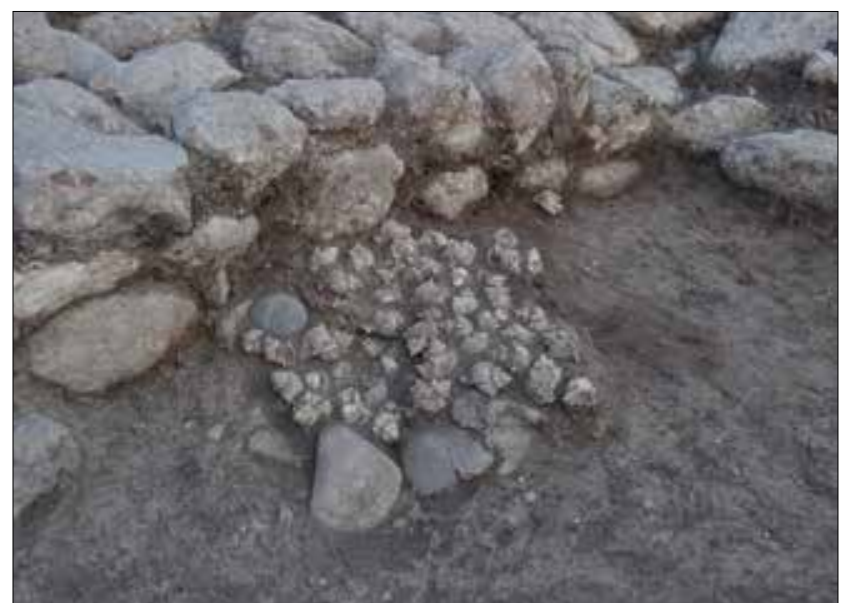

Figure 7: A pile of Hexaplex trunculus with a full-grooved stone weight all found next to the corner of Room 19 in Building $\mathrm{J}$ (Sector 1, phase III) / Tabaka III, Sektör 1 de Oda 19 içinde köşede yığın halinde yivli bir ağırlık taşı ile birlikte gün ışı̆̆ına çıkarılmış Hexaplex trunculus örnekleri

containing shells were intentionally dumped outside the buttressed wall located at the northern edge of the settlement in Sector 1. One of these deposits yielded a high quantity of Solen marginatus shells (Figs. 8-9), while the second one, two meters apart from it, contained mainly Mytilus galloprovincialis shells.

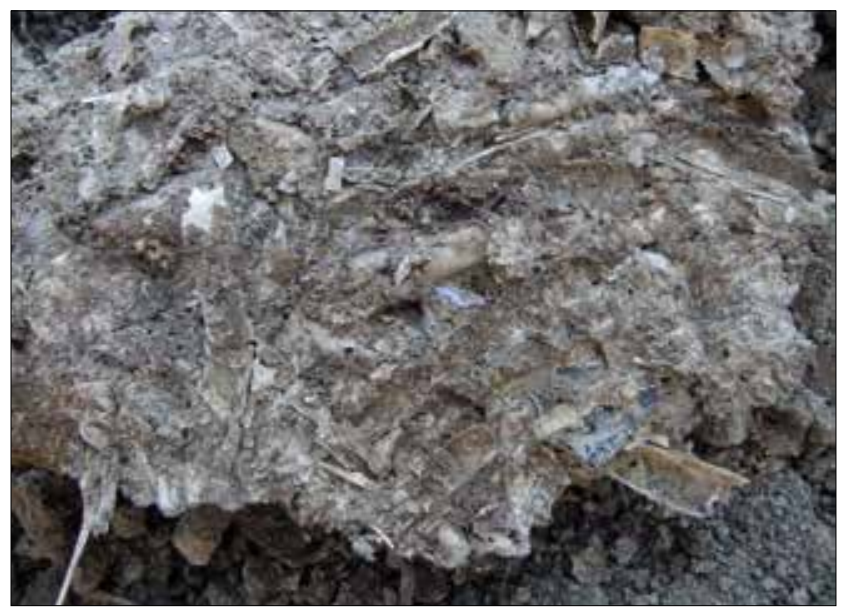

Figure 8: Detail of deposit of Solen marginatus shells found behind the northern surrounding buttressed wall in Sector 1, phase III / Tabaka III, Sektör 1 de payandalı duvarın dışında atılmış Solen marginatus yığınından bir detay

A mixture of different species of marine molluscs, dominated by such edible species as Ruditapes decussatus Solen marginatus, Patella Rustica, and Patellea coerulae, was found on the floor near a hearth in Room 14 in Building $C$ in Sector 1 . Another place where a high number of molluscs was excavated, is Room 27 in Building G. Here, marine shells were found in a clay-plastered shallow pit dug into the floor. It seems that marine molluscs were deliberately stored inside this shallow pit. The edge of 


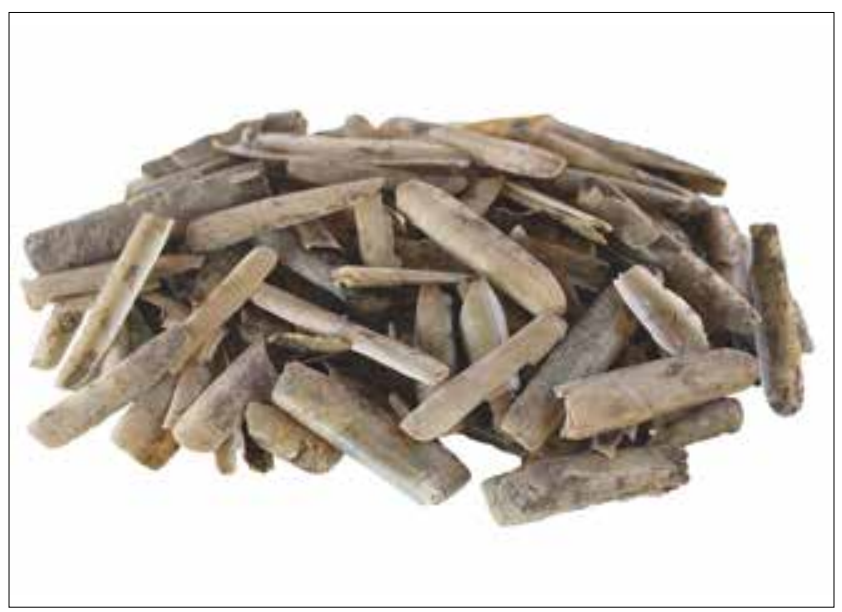

Figure 9: Some Solen marginatus shells recovered during water sieving process / Flotasyon işlemi ardından geriye kalan bazı Solen marginatus örnekleri

this shallow pit was encircled with small stones, perhaps to highlight the existence of a storage pit in this locality.

Gathering marine molluscs was one of the most exclusive sources of protein to support the diet of the prehistoric Aegean communities. The exploitation of shellfish, marine molluscs and other coastal resources has been recorded from many coastal sites as far back as the Lower Palaeolithic and increased in Early Holocene. ${ }^{6}$ The Mesolithic shellfish-gathering tradition declined during the Neolithic period and marine shell exploitation is more abundant in coastal settlements during the Neolithic period in Aegean prehistory. ${ }^{7}$ Marine mollusc gathering was also an important aspect of the Neolithic and western Anatolian communities. ${ }^{8}$ Mollusc gathering was particularly abundant at such Neolithic sites as Ulucak, Ege Gübre, Yeşilova, and Çukuriçi. ${ }^{9}$ The assemblages from these Neolithic sites are dominated by such species as Mytilus galloprovincialis, Ostrea edulis, and Cerastoderma glaucum. The present data confirm that similar subsistence strategies were adopted and continued by the succeeding Chalcolithic inhabitants of western Anatolian littoral. Gülpınar is clearly among these sites where both the Early Chalcolithic 2 and Middle Chalcolithic inhabitants relied on marine molluscs to supplement their diet. The pattern of marine mollusc exploitation documented at Gülpınar is very similar to that of other Middle Chalcolithic Troadic coastal sites, such as BeşikSivritepe and Kumtepe. ${ }^{10}$ Marine molluscs were also consumed in large amounts by the prehistoric Aegean coastal communities, while the shells remaining after

\footnotetext{
Colonese et al. 2011

Shackleton / van Andel 1986; Karali 1996, 1999.

8 Atıcı 2011; Cakırlar / Atıcı 2017.

9 Çakırlar 2015.

10 Sperling 1976; Boessneck 1986.
}

the flesh was eaten there were used to make perforated ornaments, used in dye production, tool making, and burial offerings. ${ }^{11}$

The concentration of marine shells in one location of the phase II settlement and four other locations in the phase III settlement at Gülpınar indicate that the inhabitants of the site supplemented their diet based on farming, animal husbandry, and hunting with the gathering of marine molluscs. The superfluous marine shells were occasionally used to produce personal ornaments and tools. There is unquestionably a need for further detailed studies regarding the seasonality of the marine mollusc gathering strategies adopted at Gülpınar. There was not much difference between the choice of species to be gathered between the phase II and phase III inhabitants of the site. A certain change is detectable only in nonedible species such as Phorcus turbinatus and Nassarius nitidus shells, the use of which declined from phase II to phase III at the site. The exploitation of such shells for the manufacture of decorative items such as personal ornaments has a long history in the Aegean and Mediterranean world. Because marine shells have long been valued as raw material for the manufacture of personal ornaments, certain mollusc species may have deliberately been collected from the shores. There is evidence that certain shells left over from food were also transformed into hand tools such as abrasives and burnishers that could be used in craft activities such as pot making.

\section{DISCUSSION}

The animal exploitation strategy of the inhabitants of Chalcolithic Gülpınar is based on the husbandry of sheep and goats, with goats being very slightly more abundant than sheep. Cattle are also important, perhaps more so in phase II than in phase III, but are secondary to sheep/ goats. Pig is an almost negligible minor contributor. The exploitation of wild sources is rather minimal in phase II with the exception that hunting deer and very occasionally other animals such as hare and birds. During the years of phase III, however, fish, birds, and wild mammals were harvested very intensive and the diversity of species recovered is larger. This, to some extent, might be a function of the sample size; phase III being much larger than phase II probably allowed for more species to be recovered. Even though we have more species hunted at phase III, we observe some reduction in the proportion of fallow deer and roe deer. Since phase III inhabitants were apparently interested in hunting, this reduction might indicate some degradation of the environment. Despite the fact that we have a good number of wild species exploited, the overall proportion of hunting and fishing

11 Reese 1983, 1986. 
together in the bone assemblage is very small, and none of them can be considered much more than an occasional activity. The exploitation of cattle, sheep and goats reveals a multi-purpose husbandry aimed at obtaining both meat and secondary products. Some differences are observed between phase II and phase III in that phase II settlers appear to have put more emphasis on meat whilst secondary products seem to have been more important for the phase III settlers. A good number of animals are kept to an old age, which surely points to the importance of milk and perhaps wool; the animals may also have been used for tasks involving labor.

It is difficult to compare Gülpınar with other sites not only because the Chalcolithic period is still underresearched but most importantly because there are no exact parallels for a particular date and location discussed here. A general evaluation with sites that could be broadly comparable and thus informative draws a rather heterogenous picture. Perhaps the closest contemporary economies to Gülpınar are presented by Arbuckle of two sites in Central Anatolia, the Köşk Höyük and Güvercinkayas1. ${ }^{12}$ There, sheep/goats is the most important element of the economy but their percentages of $83 \%$ and $81.4 \%$, respectively are much higher than our case. Hunting is minimal as is the exploitation of pig, resembling the case of Gülpınar. Interestingly, cattle are much less important there. For both sites, Arbuckle argues for a complex society provisioned by mobile pastoralists with a strong focus on sheep/goat as well as secondary products. ${ }^{13}$ Other evidence may include that from Aphrodisias-Pekmez ${ }^{14}$ showing sheep/goat to be less important than found at Gülpınar whilst hunting shows impressively high rates (about one third of bones recovered). In Çukurici, sheep and goats are said to increase in importance from Neolithic to the Bronze Age, indicating a pastoral economy with growing emphasis on these species. ${ }^{15}$ Kumtepe presents another trend with the emphasis on cattle and pig. ${ }^{16}$ High exploitation of sheep/goat (68\%) has also been attested in BoğazköyBüyükkaya. ${ }^{17}$ Apparently, animal exploitation in the Chalcolithic periods displays local trends and adaptation which cannot be generalized easily. What could be said is that perhaps there is a tendency for intensification of sheep/goat husbandry and pastoral economies with systematic use of secondary products.

One of the most discussed questions about the Chalcolithic is whether or not they were mostly temporary settlements or mobile populations. The main line of argument for this

\footnotetext{
12 Arbuckle 2012.

13 Arbuckle 2012.

14 Crabtree / Monge 1986

15 Horejs et al. 2011

16 Uerpmann 2003.

17 Von den Driesch / Pöllath 2004.
}

was the lack of settlements in Western Anatolia. This has been debated and somewhat dismissed as a possibility. ${ }^{18}$ From the point of view of the types of animal husbandry at Gülpınar, the low rate of pig has posed the question whether it is a nomadic culture or not. Some evidence related to seasonal activities are taken into the account here such as the neonatal remains of domestic animals as well as the utilization of wild species. Evidence has shown the presence of people at the site for possibly the late part of winter through to the spring and at least early summer. There is no more seasonal verification at present for the rest of the yearly circle. Nevertheless, the slaughter schedules of domestic animals have shown that killing happened at any age and perhaps in every season. The latter needs to be explored in more detail and in combination with isotopic analysis to be considered as confirmatory evidence; but in any case, the indication is that occupation was highly likely to have taken place all year round. The possibility of short seasonal movements or transhumance, perhaps of only some of the inhabitants, cannot also be left out of consideration.

The proximity of the site to the Aegean shore led the inhabitants of both Chalcolithic phases at Gülpınar to supplement their diet with marine molluscs such as osyters and mussels. The shallow bays located in a walking distance from the site were rich in variety of fish and marine molluscs. The quantity of marine shells clearly points to the systematic exploitation of molluscs for daily dietary purposes. The marine shell deposits were found in several locations around the hearths in the food preparation areas identified both inside buildings or in courtyards in front of the dwellings. Refuse marine shells were also found outside the surrounding wall that defines the northern part of the settlement, implying that the shells left over from meal were often dumped in empty spaces around the settlement.

\footnotetext{
18 For a recent discussion and references, see Schwall / Horejs 2018.
} 


\section{REFERENCES}

ARBUCKLE, B. S. 2012.

"Animals and inequality in Chalcolithic central Anatolia", Journal of Anthropological Archaeology 31: 302-313.

ATICI, L. 2011.

Before the Revolution: Epipaleolithic Subsistence in the Western Taurus Mountains, Turkey. Oxford.

ATICI, L. / BIRCH, S.E.P. / ERDOĞU, B. 2019

"Spread of domestic animals across Neolithic western Anatolia: New zooarchaeological evidence from Uğurlu Höyük, the island of Gökçeada, Turkey”, PlosONE (October 18): 1-30.

BOESENECK, J. 1986.

"Die molluskenfunde", Archaologischer Anzeiger, 332-337.

COLONESE, / MANNINO, A. C. / BAR-YOSEF MAYER, D.E. / FA, D. A. / FINLAYSON, J.C. / LUBELL, D. / STINER, M. C. 2011.

"Marine mollusc exploitation in Mediterranean prehistory: An overview”, Quaternary International 239: 86-103.

CRABTREE, P. J. / JONES, J.M. 1986.

"Faunal analysis", Prehistoric Aphrodisias. An Account of the Excavations and Artifact Studies (Ed. M. S. Joukowsky). Providence: 180-190.

ÇAKIRLAR, C. 2009.

"To the shore, back and again archaeomalacology of Troia”, Studia Troica 18: 59-86.

ÇAKIRLAR, C. 2015.

"Adaptation, identity, and innovation in Neolithic and Chalcolithic Western Anatolia (6800-3000 cal. BC): The evidence from aquatic mollusk shells", Quaternary International 390: 117-125.

ÇAKIRLAR, C. / ATICI, L 2017.

"Patterns of Animal Exploitation in Western Turkey from Palaeolithic molluscs to Byzantine elephants",

The Oxford Handbook of Zooarchaeology, U. Albarella, ed, Oxford, 266-279.

DAVIS, S. 1980.

"Late Pleistocene and Holocene equid remains from Israel”, Zoological Journal of the Linnean Society 70: 289-312.
GALIK, A. / THANHEISER, U. / WIESINGER, S. 2011. "Aktivitäten und Subsistenz in den Siedlungen des Çukuriçi Höyük. Der Forschungsstand nach den Ausgrabungen 2006-2009”, Prähistorische Zeitschrift 86: 31-66.

KARALI, L. 1996.

"Neolithic Jewellery of bone, shell and Stone", Neolithic Culture in Greece, G. Papathanasopoulos, /Eds. N. Hidryma and P. Goulandre). Athens: 165-166.

KARALI, L. 1999.

Shells in Aegean Prehistory, Oxford.

KOZUCH, L. / C. FITZGERALD, 1989.

"A guide to identifying shark centra from southeastern archaeological sites”, Southeastern Archaeology 8: 146-157.

MASHKOUR, M. / BURKE, A. / DOUADY, C. / EISENMANN, J. / HANNI, C. 2006.

"Geographic distribution of an extinct equid (Equus hydruntinus: Mammalia, Equidae) revealed by morphological and genetical analyses of fossils", Molecular Ecology, 15: 2083-2093.

REESE, D. S. 1983.

"The Use of Cone Shells in Neolithic and Bronze Age Greece", The Annual of the British School at Athens 78: 353-357.

REESE, D. S. 1986.

"The Mediterranean Shell Purple dye Industry", American Journal of Archaeology 90: 183-191.

REESE, D. 2006.

"The exploitation of aquatic resources at Bakla Tepe, Liman Tepe and Panaztepe", Studies in Honor of Hayat Erkanal: Cultural Reflections (Ed. A. Erkanal-Öktü/E. Özgen/S. Günel/A.T. Ökse/H. Hüryılmaz/H. Tekin/N. Çinardal1-Karaaslan/B. Uysal/F. A. Karaduman/A. Engin/R. SpieB/A. Aykurt/R. Tuncel/U. Deniz/A. Rennie), İstanbul: 626-630.

SILVER, I. A. 1969.

"The ageing of domestic animals", Science in Archaeology, (Ed. D. R. Brothwell / E. Higgs), London: 283-302.

SCHWALL, C. / Horejs, B. 2018.

"Permanent or Seasonal? Evidence of Settlements in Late Chalcolithic Western Anatolia", in Proceedings of the 10th International Congress on the Archaeology of the Ancient Near East, (Eds. B. Jorejs / C. Müller / M. Luciani / M. Ritter / M. Guidetti / R.B. Salisbury / F. Höflmayer / T. Bürger), 57-68. 
SHACKLETON, J. C. / VAN ANDEL, Tj. H. 1986.

"Prehistoric Shore Environments, Shellfish Availability, and Shellfish gathering at Franchthi, Greece", Geoarchaeology 1:127-143.

SPERLING, J. W. 1976.

"Kum Tepe in the Troad: Trial Excavation 1934", Hesperia 45 (4): 305-364.

TAKAOĞLU, T. / A. ÖZDEMIR, 2018

"The Middle Chalcolithic period in the Troad: A new look from Gülpinar", Communities in Transition: The Circum-Aegean Later Neolithic Stage (ca. 5000/48003200/3000 BC), (Eds. S. Dietz / F. Mavridis / Z. Tankosic / T. Takaoğlu), Oxford: 479-490.

UERPMANN, H.-P. 2003.

"Environmental aspects of economic changes in Troia", Troia and the Troad: Scientific Approaches. Natural Sciences and Archaeology, (Eds. A. Wagner / E. Pernicka / H.-P. Uermann), Berlin: 251-262.

VAN DEN DRIECH / PÖLLATH, N. 2004.

"Vor- und frühgeschichtliche Nutztierhaltung und Jagd auf Büyükkaya in Boğazköy-Hattuša, Zentralanatolien", Boğazköy-Berichte 7, Mainz.

YAVŞAN, Ç. 2010.

Kalkolitik Gülpınar (Smintheion) Kazları Buluntusu Deniz Kabukları. Çanakkale Onsekiz Mart Üniversitesi, Yayınlanmamış Yüksek Lisans Tezi.

WHEELER, A. / JONES. A.K.G. 1989.

"Fishes", Cambridge Manuals in Archaeology, Cambridge.

WÓJCIK, J. D. 2002.

"The comparative osteology of the humerus in European thrushes (Aves: Turdus) including a comparison with other similarly sized genera of passerine birds preliminary results", Acta Zoologica Cracoviensia, 45: 369-381. 